Наташа Диденко

\title{
ОКТОМВРИСКИ ФЕСТИВАЛИ НА НАРОДНИ ИГРИ И ПЕСНИ ВО БИТОЛА И ВО ШТИП ВО 1947 ГОДИНА (подготовка, реализација и значење)
}

\begin{abstract}
Апстракт: Трудот ги обработува првите Октомвриски фестивали на народни игри и песни, одржани во Битола и во Штип, во 1947 година. Преку методите на: историско, аналитичко и компаративно истражување, добиваме сознанија за подготовката, реализацијата и значењето на овие фестивали во современата македонска држава. Целта на трудот е да покаже дека, од една страна, фестивалите во Битола и во Штип претставувале основа за создавање на културните институции во Македонија, во чиј фокус било проучувањето на националната култура и на фолклорното творештво, а од друга страна, тие давале поттик за формирање на други културно-уметнички манифестации во Македонија, коишто како во минатото, така и денес, се стремат за зачувување и за пренесување на автентичното фолклорно наследство.
\end{abstract}

Клучни зборови: фолклор, фестивали, подготовка, реализација, значење.

Во периодот по Втората светска војна, значајно место во Македонија заземал културниот живот, а особено развојот на фолклорниот аматеризам. Речиси и да не постоело населено место без фолклорни групи, ансамбл и културно-уметнички друштва, кои од една страна ги поттикнувале културните интереси на народот, а од друга страна придонесувале за негување на песнопојното и ороводното фолклорно богатство. Меѓутоа, фолклорниот аматеризам, својата најголема валоризација и верификација во Македонија, ја добил на 3 мај 1947 година кога, по повод одбележувањето на државниот празник 11 Октомври, познат како Денот на народното востание во Македонија ${ }^{1}$, Министерството за просвета на Народна Република Македонија (натаму: НРМ), конкретно Одделението за култура и уметност, под надлежност на тогашниот министер за просвета - Никола Минчев ${ }^{2}$, донело Решение за организирање на фестивали на народни игри и песни во Битола за Западна Македонија и во Штип - за Источна Македонија (Државен архив на Република Северна Македонија (натаму: ДАРСМ), ф. 170, к. 0037, а.е. 0003, 4).

За успешно спроведување на фестивалите, коишто се именувани и како „Октомвриски фестивали на народни игри и песни“, најпрво бил формиран

\footnotetext{
1 Законот за прогласување на Денот на народното востание во Македонија за народен празник е донесен на заседанието на Президиумот на народното собрание на Македонија, одржано на 8 септември 1945 година (Закон за..., 1945, 119).

2 Никола Минчев (Кавадарци, 1915 - Скопје, 1997) - македонски комунист, политичар, учесник во НОВ. Бил назначен за прв министер за просвета на Владата на НРМ (1945 - 1948), потоа за потпретседател на Владата (1948 - 1951) и за министер за финансии (1955).
} 
Главен одбор во Скопје, како раководен и контролен орган, во состав од следните македонски културни уметници и дејци: 1) Коле Чашуле ${ }^{3}$; 2) Иван Точко ${ }^{4}$ 3) Петре Богданов - Кочко ; 4) Тодор Скаловски ${ }^{6}$; 5) Аспарух Хаџи Николов$^{7}$; 6) Мане Чучков ${ }^{8}$ 7) Лазар Личеноски ${ }^{9}$ 8) Јордан Наноски ${ }^{10}$ и 9) Лазар Кокошкаров ${ }^{11}$ (ДАРСМ, ф. 170, к. 0037, а.е. 0003, 4). Потоа се пристапило и кон формирање на одделни одбори за уредување на фестивалите во Битола и во Штип, во чиј состав, биле вклучени културни работници и претставници на масовните организации (Зографски, 1947, 42). Така, одборот за уредување на фестивалот во Битола, бил составен од: Зора Авиќ, Велко Петровски-Паскали ${ }^{12}$, Аки Павловски ${ }^{13}$, Цане Тасевски, Ибраим и Исмаил

3 Коле Чашуле (Прилеп, 1921 - Скопје, 2009) - раскажувач, романсиер, драмски писател, публицист и дипломат. По окупацијата на Југославија од страна на германските окупатори, учествувал во подготовката и кревањето на Антифашистичкото востание од 11 октомври 1941 година, а потоа и во Народноослободителната војна $(1941$ - 1944). По ослободувањето на земјата бил на разни функции во општествениот живот: директор на Радио Скопје, директор на Драмата при МНТ, главен и одговорен уредник на списанието „Разгледи“, а бил и назначен за југословенски конзул во Канада и амбасадор на СФРЈ во Боливија, Перу и во Бразил. Од 1947 година бил член на Друштвото на писатели на Македонија (натаму: ДПМ), а во 2003 година станал дописен член на Македонската академија на науките и уметностите (натаму: МАНУ) (Гилевски, 2009, 1617).

${ }^{4}$ Иван Точко (Охрид, 1914 - Скопје, 1973) - раскажувач, драмски автор. Бил уредник во „Нова Македонија“, главен уредник во Радио Скопје и на списанието „Македонија“ (Тоциновски, 2009, 1500).

5 Петре Богданов-Кочко (Скопје, 1913 - Скопје, 1988) - македонски композитор, оперски пејач (тенор) и организатор на музичкиот живот во Македонија. По формирањето на првата „Државна музикална школа“ (денес: ДМБУЦ „Илија Николовски-Луј“), во 1945 година бил назначен за наставник по соло пеење, за на 6 јуни следната, 1946, година да биде именуван за нејзин директор, на чија функција останал до 1948 година (Музичко-балейски..., 1995, 6, 106).

6 Тодор Скаловски (Тетово, 1909 - Скопје, 2004) - академик, македонски композитор, педагог, хорски и симфониски диригент и организатор на музичкиот живот во Македонија (Коловски, 1993, 197).

7 Аспарух Хаџи Николов (Скопје, 1909 - Скопје, 1980) - музички педагог и композитор. Во 1945 година бил именуван за шеф на Музичкото одделение во Министерството за просвета (Ортаков, 2009, 1579).

${ }^{8}$ Мане Чучков (Ново Село, Штипско, 1901 - Скопје, 1967) - македонски државник, универзитетски професор, општествено-политички и културно-национален деец. Во 1947 година бил поставен за директор на Заводот за домашни уметнички ракотворби „Македонски фолклор“ (Ѓоргиев, 2009, 1634 - 1635).

9 Лазар Личеноски (Галичник, 1901 - Скопје, 1964) - сликар, педагог, еден од основоположниците на македонското модерно сликарство и на Уметничкото училиште во Скопје (1945) (Неделковска, 2009, 804).

10 Јордан Наноски - комесар на просветниот отсек во Битола.

11 Лазар Кокошкаров - од град Штип.

12 Велко Петровски-Паскали, откако бил именуван за диригент на машкиот хор „Абрашевиќ“ во Битола (1933), придонел за зголемување на бројноста на пејачи хористи од 30 на 120 (1936 - 1940). На репертоарот на хорот биле застапени тогаш популарните масовни и револуционерни песни какви што се: „Марселеза“; 
Тефик, Никола Савченко ${ }^{14}$ и Владо Точковски. Од друга страна, пак, за уредување на фестивалот во Штип, во одборот биле вклучени: Стоимир Јордев, Боро Доганџијски, Драган Иванов ${ }^{15}$, Лазар Балабанов, Киро Филов, Славко Петков и Александра Бикова (Формирани..., 1947, 5). Како основна задача, пред овие одбори, било поставено да го направат изборот на најдобрите учесници за фестивалите (игроорни и пејачки групи, соло пејачи и свирачи на народни инструменти). За таа цел, организирале претфестивалски околиски смотри, коишто се одвивале по следниот распоред:

- на 14 и на 15 септември се одржале смотрите на: игроорните и пејачките групи, селските хорови и свирачите на соло инструменти во Битола за Западна Македонија:

\begin{tabular}{|c|c|c|c|}
\hline 1. & $\begin{array}{l}\text { Гевгелија, попладне на } 14 \\
\text { септември }\end{array}$ & 8. & $\begin{array}{l}\text { Ростуше, попладне на } 14 \\
\text { септември }\end{array}$ \\
\hline 2. & $\begin{array}{l}\text { Крушево, претпладне на } 14 \\
\text { септември }\end{array}$ & 9. & $\begin{array}{l}\text { Белчиште, претпладне на } \\
14 \text { септември }\end{array}$ \\
\hline 3. & $\begin{array}{l}\text { Македонски Брод }{ }^{16}, \text { попладне } \\
\text { на } 14 \text { септември }\end{array}$ & 10. & $\begin{array}{l}\text { Охрид, попладне на } 14 \\
\text { септември }\end{array}$ \\
\hline 4. & $\begin{array}{l}\text { Кичево, попладне на } 15 \\
\text { септември }\end{array}$ & 11. & $\begin{array}{l}\text { Вевчани, попладне на } 15 \\
\text { септември }\end{array}$ \\
\hline 5. & $\begin{array}{l}\text { Неготино, претпладне на } 14 \\
\text { септември }\end{array}$ & 12. & $\begin{array}{l}\text { Струга, попладне на } 15 \\
\text { септември }\end{array}$ \\
\hline 6. & $\begin{array}{l}\text { Кавадарци, попладне на } 14 \\
\text { септември }\end{array}$ & 13. & $\begin{array}{l}\text { Ресен, претпладне на } 14 \\
\text { септември }\end{array}$ \\
\hline 7. & $\begin{array}{l}\text { Дебар, претпладне на } 14 \\
\text { септември }\end{array}$ & & \\
\hline 14. & $\begin{array}{l}\text { Битола, попладне на } 14 \\
\text { септември }\end{array}$ & 21. & $\begin{array}{l}\text { Прилеп, попладне на } 14 \\
\text { септември }\end{array}$ \\
\hline
\end{tabular}

„Интернационална“; „Буди се исток и запад“; „Билеќанка“ и др. (Тодорчевска, 2009а, 5).

13 Аки Павловски - прв директор на македонскиот филмски центар „Вардар Филм“, основан 1947 година. Види повеќе кај: Божиновски, 1997.

${ }^{14}$ Никола Савченко - музички педагог со завршена Музичка академија - Солфеж. Во периодот 1949 - 1950, бил именуван за директор на Училиштето за основно музичко образование (денес ДМБУЦ „Илија Николовски-Луј“) (Музичко-балетски..., 1995, 106 $-107)$.

15 Драган Иванов (с. Рајчиловци, Босилеград, Србија, 1939) - градежен инженер и редовен професор на Градежниот факултет во Скопје (1981 - 2004) (Танчев, 2009, 584).

${ }^{16}$ Во оригиналниот документ стои Брод. 


\begin{tabular}{|c|l|l|l|}
\hline 15. & $\begin{array}{l}\text { Лазарополе, попладне на } 14 \\
\text { септември }\end{array}$ & 22. & $\begin{array}{l}\text { село Дуње, претпладне на } \\
14 \text { септември }\end{array}$ \\
\hline 16. & $\begin{array}{l}\text { Галичник, попладне на } 15 \\
\text { септември }\end{array}$ & 23. & $\begin{array}{l}\text { село Слепче } \\
\text { (Демирхисарско), } \\
\text { попладне на 15 септември } \\
\text { (ДАРСМ, ф. 170, к.0037, } \\
\text { a.е. 0045, 193). }\end{array}$ \\
\hline 17. & $\begin{array}{l}\text { Тетово, попладне на 14 } \\
\text { септември }\end{array}$ & $\begin{array}{l}\text { Гостивар, попладне на 14 } \\
\text { септември }\end{array}$ & $\begin{array}{l}\text { Теарце, претпладне на 14 } \\
\text { септември }\end{array}$ \\
\hline 18. & \multicolumn{2}{|l}{} \\
\hline 19.
\end{tabular}

- на 21 и на 22 септември, се одржале смотрите на: игроорните и пејачките групи, соло пејачите и свирачите на народни инструменти во Штип - за Источна Македонија:

\begin{tabular}{|l|l|c|l|}
\hline 1. & $\begin{array}{l}\text { Штип со околијата, попладне } \\
\text { (претпладне околијата на 21 } \\
\text { септември) }\end{array}$ & 11. & $\begin{array}{l}\text { Валандово со блиската } \\
\text { околија, претпладне на } 21 \\
\text { септември }\end{array}$ \\
\hline 2. & $\begin{array}{l}\text { Злетово - Пробиштип, } \\
\text { претпладне на 21 септември }\end{array}$ & 12. & $\begin{array}{l}\text { Дојран со блиската околија, } \\
\text { попладне на 21 септември }\end{array}$ \\
\hline 3. & $\begin{array}{l}\text { Кратово со околијата, попладне } \\
\text { на 21 септември }\end{array}$ & 13. & $\begin{array}{l}\text { Струмица, попладне на } 27 \\
\text { септември }\end{array}$ \\
\hline 4. & $\begin{array}{l}\text { Крива Паланка со околијата, } \\
\text { попладне на 22 септември }\end{array}$ & 14. & $\begin{array}{l}\text { Радовиш со околијата, } \\
\text { попладне на 22 септември }\end{array}$ \\
\hline 5. & $\begin{array}{l}\text { Кочани со околијата, } \\
\text { претпладне на 21 септември }\end{array}$ & 15. & $\begin{array}{l}\text { Маџари (Скопско), } \\
\text { претпладне на 21 септември }\end{array}$ \\
\hline 6. & $\begin{array}{l}\text { Берово со околијата, попладне } \\
\text { на 22 септември }\end{array}$ & 16. & $\begin{array}{l}\text { Драчево (Скопско), } \\
\text { попладне на 21 септември }\end{array}$ \\
\hline 7. & $\begin{array}{l}\text { Царево Село } ~ \\
\text { поп околијата, } \\
\text { подне на 22 септември }\end{array}$ & 17. & $\begin{array}{l}\text { Горче Петров со околијата, } \\
\text { попладне на 21 септември }\end{array}$ \\
\hline 8. & $\begin{array}{l}\text { Пехчево со околијата, } \\
\text { претпладне на 22 септември }\end{array}$ & 18. & $\begin{array}{l}\text { Куманово со околијата, } \\
\text { попладне на 21 септември }\end{array}$ \\
\hline 9. & $\begin{array}{l}\text { Титов Велес со дел од } \\
\text { околијата, попладне на 21 } \\
\text { септември }\end{array}$ & 19. & $\begin{array}{l}\text { Св. Николе, претпладне на } \\
\text { 21 септември (На истото } \\
\text { место, 192) }\end{array}$ \\
\hline 10. & $\begin{array}{l}\text { Богомила, во областа Азот, } \\
\text { попладне на 22 септември }\end{array}$ & \multicolumn{2}{|l}{} \\
\hline
\end{tabular}

17 Денес Град Делчево - во близина на денешната македонско-бугарска граница. 
- во периодот од 22 до 30 септември се одржувале смотрите на Градските хорови (На истото место).

На претфестивалските смотри, и покрај тоа што не било забележано само учеството на македонските игроорни и пејачки групи, соло пејачи и свирачи на народни инструменти, туку и на припадниците од другите етнички заедници во Македонија, треба да истакнеме дека интерес за учество пројавиле и поединци, односно стари познати играчи и пејачи, меѓу кои биле: 86-годишниот Стамен Темјановски од с. Велмеј, Охридско, 72-годишниот Рафе Филиповски од с. Галичник, 89-годишниот Киро Апостолски од. с. Ростуше и многу други (Предфестивалски..., 1947, 6). Всушност, со привлекувањето на интересот на помладите, а пред сѐ на постарите генерации, Октомвриските фестивали на народни игри и песни, ја разгорувале желбата, ентузијазмот и натпреварувачкиот дух на народот, со цел да се прикаже разновидноста на фолклорното богатство од Македонија. Во тој контекст А. Хаџи Николов истакнал:

Интересно е да се забележи како нашите стари мајстори - ороиграчи, чисто по природен усет и пластична инерција на покретите ги исполнуваат фигурите логично и грациозно. Младите ороиграчи треба секогаш да гледаат во играта на старите мајстори и да се учат по неа. Музиката и играта да ја разберат како една неразделна целост и во истата да даваат душевен израз на својот народ (Николов, 1947, 6).

По завршувањето на претфестивалските смотри, за учесници на фестивалот во Битола биле избрани 124 игроорни и пејачки групи, хорови, соло пејачи и свирачи на народни инструменти, од кои: 77 биле македонски, 31 албански, 4 турски, 9 ромски, 1 влашка и 2 мешани (македонско-албански), додека за фестивалот во Штип биле избрани 132 игроорни и пејачки групи, хорови, соло пејачи и свирачи на народни инструменти, од кои: 108 биле македонски, 7 албански, 9 турски и 8 ромски (ДАРСМ, ф. 170, к. 0037, а.е. $0045,188)$. Избраните учесници се натпреварувале во времетраење од три дена, односно од 9 до 11 октомври, на фестивалската сцена во Битола и во Штип.

Фестивалот во Битола се одржувал во салата на Народниот театар, каде што над бината била закачена паролата „Нашата народна култура е наша гордост“. На првиот ден, на фестивалската сцена, во претпладневните часови, најпрво зеле учество културно-уметничките друштва (натаму: КУД) од Скопје со околијата, меѓу кои биле: хорот на КУД „Кочо Рацин“"18 - Скопје, кој под

18 КУД „Кочо Рацин“-Скопје е основано на 29 септември 1946 година. За прв претседател на друштвото бил именуван Димче Бојановски-Дизе (Прилеп, 1909 Скопје, 2002), тогашен министер за трговија во Владата на НРМ. Управниот Одбор на друштвото бил составен од следните членови: Благоја Николовски - претседател на Месниот синдикален совет; Димче Мире - потпретседател на планската комисија на Владата на НРМ; Ружа Бак; Миле Јовчевски; Стеван Русјаков; Ацо Ковачевски; Коце Делчев; д-р Ѓорги Гаврилски и Раде Георгиевски. Активностите на друштвото биле 
диригентство на Живко Фирфов ${ }^{19}$ ги исполнил песните: „Македонско оро“ “20 од Т. Скаловски и „Луѓе“ од Ж. Фирфов, по кои следела и интерпретацијата на „Аранското оро“ од мешаната игроорна група на истоименото КУД.

Во продолжение следел настапот на хорот и на игроорната група на КУД „Орце Николов““-Скопје ${ }^{21}$ изведувајќи ја песната „Бригадата иде“ од П. Богданов-Кочко, а мешаната игроорна група ги извела ората „Лесната“ и „Потрчанка“. Незабележителни не останале настапите и на хорот и на игроорните групи на КУД „Братство и Единство“, II реон - Скопје (Каровски, $1947,1)$, како и на пејачот Димче Георгиев од истоименото друштво. На програмата биле застапени и соло настапите на свирачите на кавали од с. Драчево, соло пејачот и свирачот Ага Усеин, гајдаџијата Тодор Бошков, мешаната игроорна група од с. Раштак, ромската игроорна група од с. Моране, турската пејачка група со чалгија и игроорната пејачка група од стари жени (Список..., 1947, 6). Следни биле настапите на учесниците од Прилеп со околијата, меѓу кои биле забележани: настапот на синдикалниот хор КУД „Борка Левата“"Прилеп ${ }^{22}$ и мешаната игроорна група од истоименото друштво, којашто настапила со македонското оро „Чанчето“ (Каровски, 1947, 1), како и настапите на соло пејачите: Адем Асан Велимиров од Прилеп, Ристо Чавката од с. Кривогаштани, Ристо Стојаноски од Св(ето) Митрани, Тефик Мустафоски од с. Дебреште и Јанче Кузмески од с. Ропотово. Во продолжение на програмата следеле настапите на старската игроорна група од с. Кривогаштани и на женската, старската и младинската игроорна група од с. Ропотово (Список..., 1947, 6). Како последна точка од претпладневниот дел на фестивалската програма биле настапите на учесниците од Кавадарци со

организирани преку повеќе секции: фолклорна секција - под раководство на Аврам Мирчевски; литературна секција - под раководство на Љупчо Ефремов; оркестарска секција - под раководство на Васил Ќортошев и хорска секција - под раководство на Петре Богданов-Кочко (Цветаноска, 2001, 12-13).

19 Живко Фирфов (Велес, 1906 - Скопје, 1984) - истакнат македонски етномузиколог, педагог, диригент и организатор на музичкиот живот во Македонија. Види повеќе: (Диденко, 2020, 153-167,

https://journals.ukim.mk/index.php/philologicalstudies/article/view/1447).

20 Тодор Скаловски, на 18 октомври 1946 година, учествувал на конкурсот за најдобри музички творби, распишан од страна на Министерството за просвета на ФНРЈ. По одлуката на комисијата, во состав од: Михајло Вукдраговиќ и Стана Гуриик-Клајн (професори во Музичката академија во Белград) и Мирко Шпилер (член на Комитетот за радиофонија), неговата композиција „Македонско оро“ била прогласена за најдобра музичка творба на конкурсот (ДАРСМ, ф. 170, к. 0036, а.е. 0051, 377).

${ }^{21}$ КУД „Орце Николов“-Скопје било формирано во 1945 година под првобитното име „Металец“. Во јуни 1946 година било преименувано во КУД „Орце Николов“ - по името на народниот херој Јордан Николов-Орце. За прв претседател на друштвото бил назначен Страхил Гигов (Велес, 1909 - Скопје, 1999) (Диденко, 2019(а), 71).

22 Во 1946 година, на иницијатива на Данче Шиндиловски, а со дополнителна помош од просветните органи и работници, во Прилеп бил формиран првиот мешан хор (составен од мажи и жени), кој за кратко време прераснал во КУД „Борка Левата“ (Поповски, 1956, 4; Диденко, 2019, 64

https://journals.ukim.mk/index.php/philologicalstudies/article/view/316/246). 
околијата. Меѓу нив биле забележани русалиската група од с. Дреново и фронтовската група од Кавадарци со изведба на македонското „Комитско оро“ (Каровски, 1947, 1).

Програмата на фестивалот продолжила и во попладневните часови, каде што покрај настапите на градскиот хор, пејачките и женските игроорни групи, биле забележани и настапите на соло пејачите: Алтана Кочова и Митра Гелебешова од Гевгелија, Султана Попова од с. Прдејци и на соло свирачот на кавал од с. Богородица (Список..., 1947, 6). По нивните интерпретации следеле настапите на учесниците од Дебар со околијата (Лазарополе и Галичник); на учесниците од Охрид со околијата: градскиот хор „Езерски ек“ - Охрид, Охридската старска женска игроорна група, Охридската група на свирачи и пејачи „Садило“, женските пејачки и игроорни групи од с. Белчиште и с. Велмеј и на учесниците од Кичево и околијата: женската игроорна група од Кичево, албанската пејачка група од с. Зајас, игроорните групи од с. Колибари и с. Трапчин Дол, албанската пејачка група од с. Црвивци, игроорната група од с. Жубрино и пејачките групи од с. Грешница и с. Лешница. На крајот на првиот ден програмата била заокружена со настапите на учесниците од Гостивар со околијата: градскиот хор „Петре Богданов-Кочко“, градската, албанската и ромската игроорна група од Гостивар, женската игроорна група од с. Волковија, пејачката група од с. Градец, игроорните групи од с. Врапчиште, с. Вруток и др. (Список..., 1947, 6).

На вториот ден на фестивалот во Битола (10 октомври), во претпладневните часови први настапиле учесниците од Демирхисарската околија: пионерска пејачка игроорна група од с. Слепче, албанско-македонска пејачка група од с. Суводол, соло свирачи на гајда од с. Белче, инструментална група на гајда од с. Железнец, игроорната и пејачката група од с. Брезово. Следни учесници на сцената на фестивалот биле од Ресен со околијата: ромските игроорни групи од Ресен, младинската игроорна група од с. Долно Дупени, албанската игроорна и пејачка група од с. Крани и соло пејачката Родна Црноевска од Ресен. Претпладневниот дел на програмата од фестивалот била заокружена со настапите на учесниците од Крушево со околијата: игроорната група од с. Алданци; соло пејачот Кочо Штабе од Крушево, како и пејачките и игроорните групи од с. Горно Дивјаци и с. Пуста Река (Список..., 1947, 6).

Програмата на фестивалот продолжила во попладневните часови, каде што на сцената биле забележани настапите на учесниците од Тетово со околијата: КУД „Иљо Антески-Смок“-Тетово ${ }^{23}$; градскиот синдикален хор, старската женска, мешана и албанската машка игроорна група од Тетово; женскиот хор на АФЖ од Тетово; соло свирачи на кавали и на шупелка, како и машката и мешана игроорна група од с. Теново. Меѓу учесниците биле и албанската пејачка и игроорна група од с. Шемшево; соло свирачот на кавал

${ }^{23}$ КУД „Иљо Антевски-Смок“ било формирано на 28 декември 1946 година од страна на Месниот синдикален совет во Тетово. Друштвото било составено од поранешните членови на предвоените тетовски музички друштва „Бинички“, „Кирил Пејчиновиќ“ и „Братство“ (Светозаревиќ, 2017, 76, 72). 
од с. Теарце; пејачките групи од с. Брвеница и Тетово. Потоа следеле настапите на учесниците од Македонски Брод со околијата: игроорна група од Македонски Брод; игроорни и пејачки групи од с. Дворци и с. Ижиште, како и настапот на мешаната игроорна пејачка група од с. Крушје. Програмата на вториот ден од фестивалот била затворена со настапите на учесниците од Битола со околијата: синдикалниот хор „Стиф Наумов“-Битола; игроорната група на IV маало од Битола; игроорната група од с. Бач; влашката игроорна група од с. Нижеполе; мешаната игроорна група од с. Гермијан; како и настапите на соло пејачите: Трајана Борисова од с. Добрушево, Тошко МицевЈоле од с. Алинци ${ }^{24}$ и Степан Марков Ацевски од с. Дедебалци (Список..., 1947, 6).

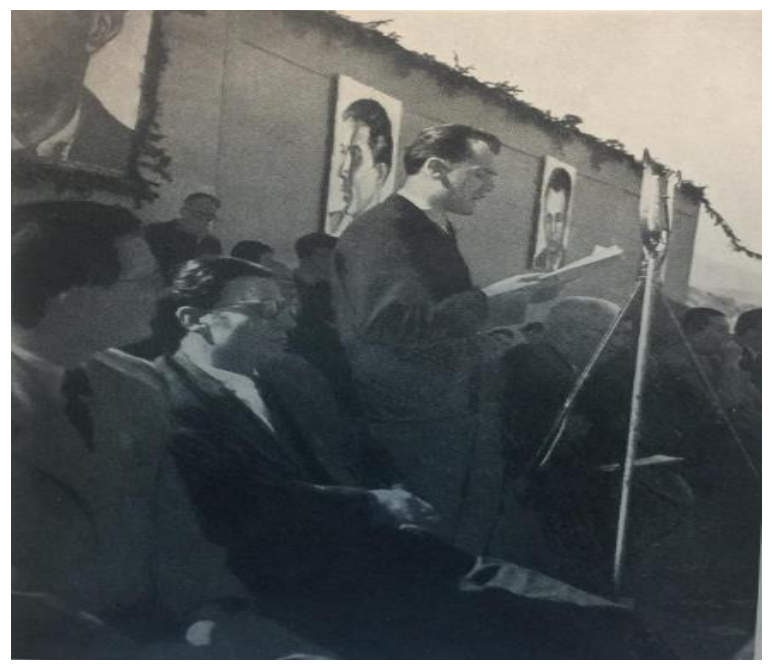

Слика бр. 1: Октомвриски фестивал во Битола - поздравен говор на Киро Хаџи Василев (министер за Народна просвета на НРМ) $)^{25}$

Завршната програма на фестивалот (на 11 Октомври), започнала со парада на сите учесници, којашто, покрај широкиот аудиториум, била следена и од: Димитар Влахов - потпретседател на Президиумот на Народното собрание на Федеративна Народна Република Југославија (натаму: ФНРЈ); Лазар Колишевски - претседател на Владата на НРМ; Бане Андреев и д-р Димитар Несторов - министри од Сојузната влада; Страхил Гигов претседател на Единствените синдикати на Македонија и други гости (Каровски, 1947a, 1). По нејзиното завршување, со поздравен говор се обратил

${ }^{24}$ Во написот пишува Аглорци.

25 Сликата е преземена од: Фестивали на народни песни и игри Битола - Штип, 11.Х.1947. (Без место): Државно књигоиздателство на Македонија (страните не се пагинирани). 
министерот за Народна просвета на НРМ - Киро Хаџи Василев ${ }^{26}$ (види сл. бр.1), кој рекол:

Денешниот празник е увеличан со две големи културни манифестации на нашиот народ - фестивалите на народни песни и игри во Битола и Штип. Не случајно тие културни манифестации се сврзани со денот на востанието. Можеме слободно да кажеме дека 11 октомври 1941 година претставуе, покрај другото и почеток на новата културна преродба ${ }^{27}$ на македонскиот народ. Сите наши денешни победи, па и нашата денешна прослава, се резултат на победничкото востание дигнато на 11 октомври. Од тој ден македонскиот народ започна да внесуе во својата национална култура нови културни цености, од тој ден датираат првите негови победнички традиции, од тој ден, тој започна да ги уништуе не само фашистичките агресори и нивните слуги, туку и да ги отстрануе сите фактори на вековното ропство и со тоа да си отвара пат кон слободен политички, економски и културен развиток. Денешните фестивали се чест на народно-ослободителната борба почната на 11 октомври и ние најправилно го оцртуеме културниот значај на денот на востанието сврзувајќи ги фестивалите со него (Каровски, 1947a, 1).

По завршувањето на говорот биле прогласени победниците на фестивалот, оценети од страна на жири-комисија, во состав од: Владо Малевски ${ }^{28}$, Иван Точко, Лазар Личеноски, Димче Коцо ${ }^{29}$, А. Хаџи Николов, Стојан Крстевски ${ }^{30}$ и Ордан Миневски. Меѓу гостите биле и Богоје Фотев претседател на Президиумот на Народното собрание на Македонија; културни работници од Чехословачка; претставници на Комитетот за култура и уметност при владата на ФНРЈ; гости од другите народни републики и сл. (Каровски, 1947, 1). Наградите биле поделени во три категории и тоа: а) Наградени учесници од прва категорија: прва награда му била доделена на хорот на КУД „Иљо Антески-Смок“-Тетово, додека втората награда ја делеле синдикалниот хор „Стиф Наумов“-Битола, со хорот на КУД „Кочо Рацин“Скопје и со хорот на КУД „Борка Левата“-Прилеп; б) Наградени учесници од втора категорија: прва награда му била доделена на градскиот хор „Петре Богданов-Кочко“-Гостивар; втора награда - на хорот на КУД „Братство и

${ }^{26}$ Киро Хаџи Василев - по ослободувањето, од 1945 до 1946 година, бил назначен за директор на „Нова Македонија“, потоа за министер за Народна просвета на НРМ. Во периодот од 1951 до 1953 година, бил началник во Министерството за надворешни работи, потоа советник на Амбасадата на ФНРЈ во Анкара, а од јануари 1955 година, бил именуван за генерален конзул на ФНРЈ во Истанбул (Ко је ко..., 1957, 233).

${ }^{27}$ Во оригиналниот напис стои: културна приредба.

${ }^{28}$ Владо Малески (Струга, 1919 - Струга, 1984) - раскажувач, романсиер, втемелувач на современата македонска проза, сценарист, публицист, новинар. Бил директор на Радио Скопје и уредник на списанијата „Нов ден“, „Современост“ и „Разгледи“. Покрај тоа, бил назначен и за амбасадор во: Либан, Етиопија и Полска. Од 1946 година бил член на ДПМ (Мојсова, 2009, 902).

29 Димче Коцо (Охрид, 1910 - Скопје, 1993) - прв македонски историчар на уметноста, академик, декан на Филозофскиот факултет во Скопје.

${ }^{30}$ Стојан Крстевски (Долнени, Прилепско, 1914 - Скопје, 1987) - виолински педагог и прв директор на Училиштето за основно музичко образование (Денес: ДМБУЦ „Илија Николовски-Луј“) (Музичко-балет̄ски..., 1995, 14 - 15). 
Единство“, II реон - Скопје, и трета награда - на хорот на КУД „Орце Николов“-Скопје (Каровски, 1947a, 2). Во оваа категорија биле вклучени и игроорните групи, коишто биле наградени со следните награди: првата награда им била доделена на игроорната група Русалии од с. Петрово, Гевгелиска околија и на Игроорната група од с. Лазарополе, Дебарска околија, додека пак втората награда им била доделена на Игроорната група од с. Раштак, Скопска околија и на ромската Игроорна група „Братство и Единство“, II Реон - Скопје; в) Пофалници добивале учесниците од трета категорија односно сите оние што не биле наградени со некоја од првите три награди. По доделувањето на наградите, во текот на попладневните часови, учесниците славеле на стадионот и на плоштадот во Битола, а во вечерните часови во Народниот театар бил одржан Концерт на наградените учесници (ДАРСМ, ф. 170, к.0037, а.е.0045, 232).

Фестивалот во Штип се одвивал по истата програма како и фестивалот во Битола. Се одржувал во Фискултурниот дом од 9 до 11 октомври, а програмата на фестивалот во претпладневните и попладневните часови била исполнета со настапите на избраните игроорни и пејачки групи, хорови, соло пејачи и свирачи на народни инструменти. Меѓу нив биле забележани настапите на учесниците од Скопје со околијата: хорот и мешовитата игроорна група на Железничкото КУД „Владо Тасевски“-Скопје ${ }^{31}$ и на КУД „Кузман Јосифовски-Питу“, ПТТ-Скопје. По нив следеле настапите на учесниците од Куманово со околијата: синдикален хор, женска и старинска машка игроорна група од Куманово; машка игроорна група од с. Шупљи Камен; машка игроорна група од с. Винце; албанска игроорна група од с. Никуштак; како и настапите на соло пејачите: Трајко Самарџија, Става и Стојко Шајков од Куманово. Меѓу учесниците биле и соло свирачите на народни инструменти: Трајан Макрешевски - соло свирач на гајда и Душан Кирев - свирач на дудук, двајцата од с. Пчиња. Во продолжение на програмата следеле настапите на учесниците од Пиринска Македонија и на учесниците од Струмица со околијата: градскиот хор, женската игроорна и пејачка група од Струмица; соло пејачката Ленка Малинова од Струмица; женската и мешаната игроорна група од с. Смолари; младинскиот хор од с. Моноспитово; русалиската игроорна група од с. Секирник; како и женската игроорна група од с. Нивичино (Список..., 1947, 6).

На фестивалот биле забележителни настапите и на учесниците од Крива Паланка со околијата: женската игроорна група од Крива Паланка; соло свирачот Славе Стојанов од с. Псача и мешаната игроорна група од с. Кркља. Учесници имало и од Радовиш со околијата: градскиот хор, женската и младинската турска игроорна група од Радовиш; машката игроорна група од с. Липовиќ; женската игроорна група од с. Конче; машката игроорна група од с.

31 ЖКУД „Владо Тасевски“ е првото културно-уметничко друштво во Скопје, формирано на 12 мај 1945 година. Друштвото активностите ги спроведувало преку повеќе секции: драмска, рецитаторска, игроорна секција и оркестар, а подоцна на иницијатива на Стефан Гајдов, бил основан и мешан хор на железничарите (Тодорчевска, 2004, 395). 
Ракитец; турската игроорна и пејачка група од с. Калуѓерица; младинската и машката игроорна група од с. Ињево; машките игроорни групи од с. Габревци; с. Загорци и од с. Дедино. На сцената се претставиле и учесници од Царево Село со околијата: градскиот хор и мешаната ромска игроорна група од Царево Село; пејачката игроорна и женската пејачка група (со српови) од с. Разловци; соло пејачот (со гусла) - Никола Мазев од с. Ветрен; турската игроорна група од с. Град; соло свирачот на гајда - Стоичко Захариев и машката игроорна група од с. Киселица и с. Драмче (Список..., 1947, 6).

Како дел од Штипската фестивалска програма биле и настапите на: игроорните и пејачките групи, хоровите, соло пејачите и свирачите од Титов Велес со околијата. Меѓу нив биле: градскиот хор и игроорните групи од Титов Велес; турските игроорни групи од с. Виничани и с. Оризари; мешаните игроорни групи од с. Лисиче и с. Богомила; игроорните групи од с. Јаболчиште и с. Папрадиште и старската машка игроорна група од с. Подлес. Во текот на програмата биле забележани и настапите на учесниците од Берово со околијата: градскиот хор, машката и женската игроорна група од Берово; како и настапите на соло пејачите Димитар Штрбевски и Драга Марковска од Берово; потоа учесниците од Ѓорче Петров со околијата: игроорна група од с. Бардовци; свирачи на кавали од с. Буковиќ; машката игроорна група од с. Волчи Дол; ${ }^{32}$ ромската мешана игроорна група од с. Сарај и др. Учесници на фестивалот имало и од Кратово со околијата; Кочани со околијата и Валандово и Дојран. Меѓу тие учесници биле: градскиот хор, пејачката и игроорната група од Кратово; игроорната група од работниците на рудникот 'Пробиштип'; женската игроорна и пејачка група од с. Злетово, машката игроорна група од с. Бунеш; градскиот хор, ромската и турската игроорна група од Кочани; младинскиот хор од с. Виница; машката пејачка и женската игроорна група од Валандово; мешаната пејачка група од с. Јосифово и женската пејачка и игроорна група од с. Грчиште. На вториот ден фестивалската програма била затворена со настапите на учесниците од Штип со околијата: градскиот синдикален хор и игроорни групи од Штип; мешаната пејачка група од с. Крупиште; старската машка игроорна група од с. Врсаково; мешаните пејачки и игроорни групи од: с. Долно Трогерци, с. Драгоево, с. Лесковица и сл. (Список..., 1947, 6).

32 Денес Волково - село во општина Ѓорче Петров. 


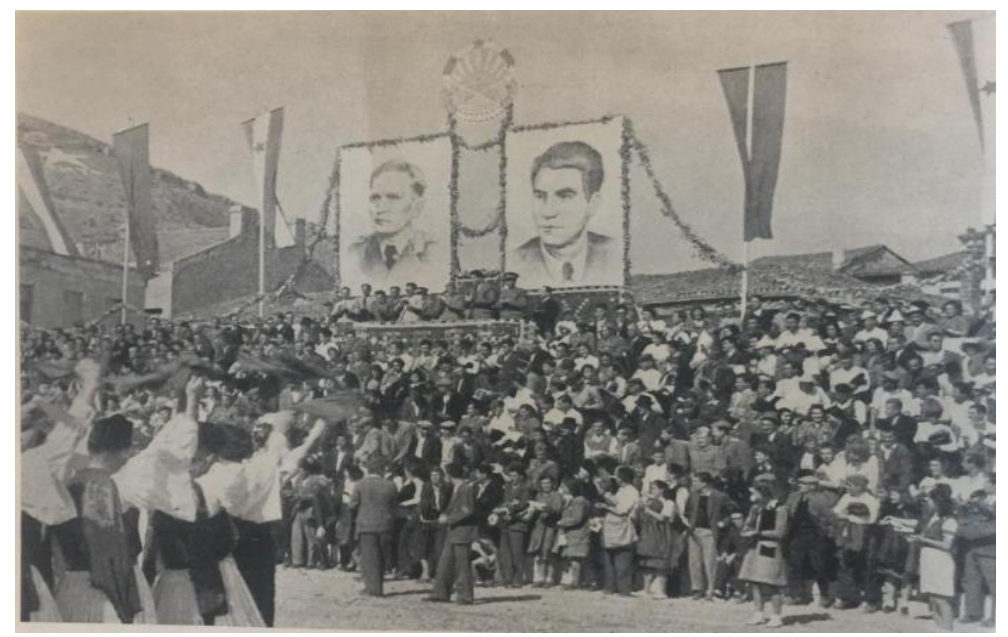

Слика бр. 2: Дел од атмосферата на Октомвриски фестивал во Штип ${ }^{33}$.

На последниот ден (11 октомври), се прогласувале победниците на фестивалот во Штип. Меѓу оние што ја следеле програмата на фестивалот биле: Љупчо Арсов - потпретседател на Владата на НРМ и претседател на Контролната комисија; Н. Минчев - министер без портфељ и втор секретар на Главниот Одбор на Народниот Фронт (натаму: НФ) на Македонија; Вера Ацева - секретар на Градскиот Одбор на НФ од Скопје; Димче Беловски претседател на Земскиот одбор на Народната младина на Македонија; Крсте Марковски - секретар на Земскиот одбор на Народната младина на Македонија; како и министрите: Тоде Ношпал; Даре Џамбаз; Васил Калајџиски; Киро Петрушев; Крсте Симоски и др. (види сл. бр. 2). На фестивалот имало присутни гости и од Пиринска Македонија и од другите народни републики. Исто така, меѓу гостите бил и Вељко Влаховиќ - шпански борец и публицист од Белград (А(постолски), 1947, 2).

По завршувањето на парадата, Ристо Каливков - секретар на Градскиот одбор на НФ во Штип, со поздравен говор ја отворил свеченоста на фестивалот од името на Владата на НРМ, по кого се обратил и Н. Минчев, кој рекол:

Три години го славиме 11 октомври во услови на усилена изградба на нашата заедничка татковина. Три години македонскиот народ го дочекуе 11 октомври со нови и со поголеми успеси на сите полиња од општествениот, политичкиот, стопанскиот и културниот живот. Нашата убава земја се изградуе сѐ повеќе. Нашето заостанато стопанство стануе се понапредно и посилно. Нашите широки работни маси имаат се покултурен и поубав живот. Оваа година прославувањето на 11 октомври е увеличано и со одржувањето на масовни

33 Сликата е преземена од: Фестивали на народни песни и игри Битола - Штип, 11.Х.1947 (Без место), (Без датум): Државно књигоиздателство на Македонија (страните не се пагинирани). 
културни манифестации, кои што се од особено значење за нашата млада национална култура. Оваа година 11 октомври го прославуваме и со одржувањето на фестивали на народни игри и песни. Тој факт е карактеристичен за тоа колку нашата власт е длабоко заинтересирана да ја изгради што поубаво, што повисоко да ја издигне, и упати по правилен пат нашата национална култура (А(постолски), 1947, 2-3).

По завршувањето на говорот, П. Богданов-Кочко, како еден од претставниците на жири-комисијата на фестивалот, започнал да ги прогласува победниците. Нивните награди, исто како и на фестивалот во Битола, биле поделени во три категории: а) Наградени учесници од прва категорија: прва награда му била доделена на хорот на ЖКУД „Владо Тасевски“-Скопје; втората награда им била доделена на Градскиот хор од Куманово; на Хорот на КУД „Кузман Јосифовски-Питу“ и на Градскиот хор од Штип. Во оваа категорија биле наградени и игроорните групи, при што: прва награда им била доделена на албанската машка Игроорна група од Кумановска околија и на машката Игроорна група од с. Киселица, Царевоселска околија; потоа втората награда ја делеле машката Игроорна група од с. Бардовци, Горче Петровска околија, со машката Игроорна група од с. Буковиќ, Ѓрче Петровска околија, со Игроорната група од с. Горно Броди - Серско и со ромската машка Игроорна група од Куманово, додека третата награда им била доделена на други осум игроорни групи; б) Наградени учесници од втора категорија: прва награда им била доделена на Хоровите од Титов Велес и Кочани; втора награда на Хорот од Кратово и трета награда на Хоровите од Берово и Струмица и в) Пофалници добивале учесниците од трета категорија односно сите оние што не биле наградени со некоја од првите три награди. По доделувањето на наградите, во текот на попладневните часови, учесниците славеле, а во вечерните часови во Фискултурниот дом бил одржан Концерт на наградените учесници (А(постолски), 1947, 3).

На самиот крај можеме да заклучиме дека Октомвриските фестивали на народни игри и песни го привлекле интересот на: многубројни игроорни и пејачки групи, соло пејачи и свирачи на народни инструменти, од градовите и од околиите на Западна и на Источна Македонија. Значењето на овие фестивали, од една страна, го гледаме во тоа што за прв пат, македонскиот народ и другите етнички заедници во современата македонска држава, имале можност да го прикажат целокупното фолклорно творештво пред пошироката јавност, на автентичен начин. Со тоа, всушност, пред избраните Одбори, пододбори и комисии, се поставила одговорна задача за собирање на фолклорното богатство и за негова систематска и студиозна разработка, којашто претставувала основа за создавање на културните институции во Македонија, за проучување на националната култура и на фолклорното творештво. Меѓутоа, од друга страна, значењето на фестивалите го гледаме во тоа што, со нивното востановување, се дало можност да се види што е потребно за опстојувањето и за континуитетот на народната култура и на традиционалните вредности. Во таа смисла, во подоцнежниот период се покажало дека овие фестивали претставувале поттик за формирање на други 
културно-уметнички манифестации во Македонија, коишто, како во минатото, така и денес, се стремат за зачувување и за пренесување на автентичното фолклорно наследство.

\section{ЛИТЕРАТУРА}

А(ПОСТОЛСКИ), В. (1947). „Да го изнајдеме, запазиме и понатаму развиеме нашето народно културно богатство“. Нова Македонија, год. IV, бр. $858,2-3$.

БОЖИНОВСКИ, М. (1997). Се сеќаваме ли на Аки Павловски - првиот директор на „Вардар филм“. Скопје: Кинотека на Македонија.

ГИЛЕВСКИ, П. (2009). Коле Чашуле. Македонска енцииклопедија, кн. 2, гл. ред. Блаже Ристовски. Скопје: МАНУ, 1617.

ДИДЕНКО, Н. (2019). „Појавата и бројноста на културно-уметничките друштва во Македонија (1945 - 1963)“. Philological studies, vol. XVII, issue 2. Перм - Љубљана - Скопје - Загреб - Белград, 63-81.

https://journals.ukim.mk/index.php/philologicalstudies/article/view/316/246

ДИДЕНКО, Н. (2019а). Развојот и дејноста на музичките културноуметнички организации и манифестации во Македонија. Музички културноуметнички организации, т. 1. Скопје: Дирекција за култура и уметност.

ДИДЕНКО, Н. (2020). „Улогата на македонскиот композитор и етномузиколог Живко Фирфов во современата македонска музичка култура“. $\begin{array}{llllll}\text { Philological studies, } & \text { 6. } & 18, & \text { 6p. } & 2, & 153-167\end{array}$ https://journals.ukim.mk/index.php/philologicalstudies/article/view/1447.

ГОРГИЕВ М., Ѓ. (2009). Чучков, М. (Е.) Христов. Македонска енциклопедија, кн. 2, гл. ред. Блаже Ристовски. Скопје: МАНУ, 1634-1635.

Закон за прогласување на денот на народното востание во Македонија за народен празник (1945). Службен весник на федерална Македонија, бр. 20, 119.

ЗОГРАФСКИ, Д. (1947). „Октомвриските фестивали во Битола и Штип“. Нов ден (списание за уметност наука и општествени прашања), бр. 7, 42-50.

КАРОВСКИ, Л. (1947). „Вчера во Битола и Штип отпочна смотрата на нашата богата народна уметност“. Нова Македонија, год. IV, бр. 856, 1.

КАРОВСКИ, Л. (1947а). „Свечена прослава на народниот празник 11 окто(м)ври во нашата Народна Република. Само под условите на народна власт нашиот народ можеше така брзо и видно да ги разгрне своите творечки сили и да ја манифестира својата богата култура“. Нова Македонија, год. IV, бр. $858,1-2$.

Ко је ко у Југославији, биографски податоции о југословенским савременицима, т. 1 (1957). Ред. Јанковиќ, С. и М. Милановиќ. Београд, 233.

КОЛОВСКИ, М. (1993). Македонски композитори и музиколози. Скопје: Сојуз на композиторите на Македонија.

МОЈСОВА-ЧЕПИШЕВСКА, В. (2009). „Малески Владо“. Македонска ени̧иклопедија, кн. 2, гл. ред. Блаже Ристовски. Скопје: МАНУ, 902-903. 
ПИСИНОВА, М. (гл. ред.). 1995. Музичко-балетски училишен иентар „Илија Николовски-Луј “. Скопје: Музичко балетски училиштен центар „Илија Николовски-Луј“.

НЕДЕЛКОВСКА, Л. (2009). „Личеноски Лазар“. Македонска енциклопедија, кн. 1, гл. ред. Блаже Ристовски. Скопје: МАНУ, 804.

НИКОЛОВ ХАЏИ, А. (1947). „За некои кореографски моменти во нашите ора. По повод октомвриските фестивали на народни песни и ора во Битола и Штип“. Нова Македонија, год. IV, бр. 804, 6.

ОРТАКОВ, Д. (2009). „Хаџи Николов Аспарух“. Македонска енциклопедија, кн. 2, гл. ред. Блаже Ристовски. Скопје: МАНУ, 1579.

ПОПОВСКИ, П. (1956). „Една деценија културно-уметничка работа: разговор со Данче Шиндиловски, иницијатор за оснивање на КУД 'Борка Левата' во Прилеп“. Нова Македонија, год. XII, бр. 3506, 4.

„Предфестивалски смотри во западна Македонија“ (1947). Нова Македонија, год. IV, бр. 837, 6.

СВЕТОЗАРЕВИК-ПОКОРНИ, Б. (2017). Културно пулсирање низ времето (1922 - 1947 - 2017): монографија. Тетово: Здружение за култура и уметност „Иљо Антески-Смок“.

„Список на играорските и пеачки групи, како и хорови и соло играчи, пеачи и свирачи што ќе земат учество на фестивалите во Битола и Штип од 9 до 11 октомври 1947 година“. (1947). Нова Македонија, год. IV, бр. 853, 6.

ТАНЧЕВ, Љ. (2009). Иванов Драган. Македонска енщиклопедија, кн. 1, гл. ред. Блаже Ристовски. Скопје: МАНУ, 584.

ТОДОРЧЕВСКА, Ј. (2004). Сто македонски години: 1903 - 2003: енциклопедиски лексикон, гл. ред. Јован Павловски. Скопје: МИ-АН, 395.

ТОДОРЧЕВСКА, J. (2009a). „Абрашевиќ“, Машки хор, Битола. Македонска енциклопедија, кн. 1, гл. ред. Блаже Ристовски. Скопје: МАНУ, 5.

ТОЦИНОВСКИ, В. (2009). „Точко Иван“. Македонска енциклопедија, кн. 2, гл. ред. Блаже Ристовски. Скопје: МАНУ, 1500.

„Фестивали на народни песни и игри Битола - Штип, 11.Х.1947“. (Без место): Државно књигоиздателство на Македонија.

„Формирани се одборите за уредуење на фестивалите во Битола и Штип“. (1947). Нова Македонија, год. IV, бр. 761, 5.

ЦВЕТАНОСКА, К. (2001). Ансамбл за народни песни и ора „Кочо Ращин “. Скопје: Ансамбл за народни песни и ора „Кочо Рацин“.

\section{АРХИВСКИ ИЗВОРИ}

ДАРСМ, ф. 170, Министерство за просвета (1945 - 1951), Решение за организирање на фестивали на народни игри и песни во НРМ и формирање Главен одбор и главно раководство на фестивалите, к. 0037, a.e. 0003, 4.

ДАРСМ, ф. 170, Министерство за просвета (1945 - 1951), Прегледи за бројот на играорните и пејачките групи, соло пејачите и свирачите на народни песни и инструменти, к. 0037, а.е. 0045, 188. 
ДАРСМ, ф. 170, Министерство за просвета (1945 - 1951), Материјали од одржани фестивали во Штип и Битола во периодот од 14 до 30 септември и 11 октомври 1947 година и тоа: план на смотрите, к.0037, a.e. 0045, 192-193.

ДАРСМ, ф. 170, Министерство за просвета (1945-1951), Програма на фестивалот на народни игри и песни во Битола, к. 0037, а.е. 0045, 231-232.

ДАРСМ, ф. 170, Министерство за просвета (1945 - 1951), Доделени се наградите за најдобри музички творби по конкурсот што го распиша Министерството за просвета, к. 0036, а.е. 0051, 377.

Natasha Didenko

\section{OCTOBER FESTIVALS OF FOLK DANCES AND SONGS IN BITOLA AND SHTIP IN 1947 \\ (preparation, realization and meaning)}

\section{Summary}

In this paper the first October Festival of Folk Dances and Songs are covered which were performed in Bitola and Shtip in 1947. The historical, analytical and comparative methods were used. Based on that, we point out the preparation, realization and the meanings of these festivals in the Contemporary Macedonian State. The purpose of this paper is to show that the Festivals in Bitola and Shtip gave contribution for the establishment of cultural institutions in Macedonia, and the focus was the research of the national culture and folklore. These activities also served as an initiative for the establishment of other cultural-artistic manifestations in Macedonia, which, as in the past and also today, gave incentive for the preservation and transmission of the authentic folklore heritage. 